\title{
A comparison of two modelling studies of environmental effects on forest carbon stocks across Europe
}

\author{
Ronnie MILNE*, Marcel VAN OIJEN \\ Centre for Ecology \& Hydrology, Bush Estate, Penicuik, Midlothian, EH26 0QB, United Kingdom
}

(Received 13 April 2004; accepted 15 April 2005)

\begin{abstract}
Two modelling approaches to describing the variation in the carbon balance of forests in different parts of Europe are presented. A forest growth model (Eurobiota) was parameterised for 3 eco-climatic zones. The parameter values were derived from process-based forest growth models developed to describe the situation at forest locations within each zone. The model was separately run for conifers and broadleaves on a 30' grid across Europe. Daily climate data covering the period from 1830 to the present and then projected to 2100 were used. European forests were shown to be a net sink of carbon of $0.06 \mathrm{Pg} \mathrm{y}^{-1}$ at present. The Boreal and Temperate zones are likely to continue at their present rate or more for the next century but the net sink in the Mediterranean zone may become smaller due to projected drier conditions. The effect of temperature using the surrogate of latitude on net ecosystem productivity is also discussed. A complex forest growth model (EFM) was parameterised for Norway spruce and Scots pine, and tested against measurements from 22 forest locations across Europe. This second model showed that the main driver of increased forest growth in the 20th century has been increased nitrogen deposition, rather than increased $\left[\mathrm{CO}_{2}\right]$ or climate change, as indicated by EuroBiota. Increased growth has led to increased carbon storage in the system, but most of it in tree biomass rather than stably sequestered in recalcitrant soil organic matter. Carbon stocks were increased more in Central Europe than in Scandinavia, except for some high-fertility sites where N-deposition had little impact. The EFM model was also used to predict the effects of future environmental change, and suggested that climate change and $\left[\mathrm{CO}_{2}\right]$ may become the dominant environmental drivers for forest carbon exchange. The two models thus give similar results when considering only climate change and $\left[\mathrm{CO}_{2}\right]$ but EFM can in addition describe the effects of N-deposition when appropriate.
\end{abstract}

European forests / carbon balance / modelling / climate change

Résumé - Comparer les impacts de facteurs environnementaux sur les stocks de carbone des forêts européennes : deux exercices de modélisation. Cette étude présente deux approches de modélisation permettant de décrire la variabilité du bilan de carbone des forêts européennes. En premier lieu, le modèle de croissance d'arbres, Eurobiota, fut paramétré pour trois zones éco-climatiques différentes. Les valeurs des paramètres furent dérivées de modèles basés sur les processus simulant la croissance d'arbres dans chacune ces zones. Le modèle fut exécuté séparément pour les conifères et les feuillus, sur une grille de modélisation de 30' à travers l'Europe. Une base de données climatique à échelle quotidienne fut utilisée, couvrant une période de 1830 jusqu'à maintenant, et projetée jusqu'en 2100. Cet exercice de modélisation démontre que les forêts européennes actuelles représentent un puits de carbone de $0.06 \mathrm{Pg} \mathrm{an}^{-1}$. Dans les zones boréales et tempérées, il est probable que ce taux d'accumulation demeure ainsi mais pourrait aussi s'accroître au siècle prochain. Cependant, dû aux conditions climatiques prévues plus arides, le puits net méditerranéen pourrait décroître. Une discussion sur les effets occasionnés par la substitution de la température par la latitude pour simuler la productivité nette est aussi présentée. En second lieu, un modèle complexe basé sur les processus (EFM) fut paramétré pour l'épicéa (Norway spruce) et le pin sylvestre (Scots pine) et testé à partir de données en provenance de 22 forêts européennes. Ce dernier modèle démontre qu'au $\mathrm{XX}^{\mathrm{e}}$ siècle, le dépôt d'azote plutôt que les changements climatiques ou l'accroissement de $\mathrm{CO}_{2}$, tel que suggéré par Eurobiota, détermine principalement l'augmentation du taux de croissance des forêts. De plus, cette augmentation conduit à une accumulation de carbone dans le système se retrouvant principalement dans la biomasse des arbres plutôt que de manière stable dans la matière organique récalcitrante du sol. Les stocks de carbone de l'Europe centrale s'accroissent plus que ceux de Scandinavie, à l'exception des sites scandinaves hautement fertiles, où le dépôt d'azote influence peu la croissance. EFM fut aussi exécuté afin de prédire les impacts des changements climatiques futurs sur les échanges de carbone. Celui-ci indique que dans le futur, ce sont les changements climatiques ainsi que le $\mathrm{CO}_{2}$ qui risquent de devenir les principaux facteurs déterminant de ces échanges. Les deux modèles démontrent des résultats similaires en ce qui a trait aux changements climatiques et au $\mathrm{CO}_{2}$. Cependant, EFM permet également de décrire l'influence du dépôt d'azote.

forêts européennes / bilan de carbone / modélisation / changement climatique

\section{INTRODUCTION}

Assessing the effect of climatic and environmental variables on forest growth and hence carbon exchange can be approached in a number of ways. Penman et al. [14] have described methods for preparing annual inventories of changes in stocks of carbon in forests in the context of the UN Framework Convention on Climate Change (UNFCCC). In their guidance they presented

\footnotetext{
* Corresponding author: rmilne@ceh.ac.uk
} 
Table I. Comparison of methodology and complexity of EFM and Biota models.

\begin{tabular}{|c|c|c|}
\hline & EFM & Biota \\
\hline Model type & $\begin{array}{c}\text { Deterministic, } \\
\text { non-spatial, pool-based }\end{array}$ & $\begin{array}{l}\text { Deterministic, spatial, } \\
\text { pool-based }\end{array}$ \\
\hline No. State variables & 50 & 7 \\
\hline No. Parameters & 261 & 40 \\
\hline Time step & $<$ hourly & daily \\
\hline Input variables & $\begin{array}{c}\mathrm{CO}_{2} \text {, Radiation, } \mathrm{T}_{\max }, \\
\mathrm{T}_{\min } \text {, Rain, } \mathrm{RH}, \text { wind, } \\
\text { N-deposition }\end{array}$ & $\begin{array}{c}\mathrm{CO}_{2} \text {, Radiation, } \mathrm{T}_{\max }, \\
\mathrm{T}_{\text {min }} \text {, Rain, vpd }\end{array}$ \\
\hline Ecosystem fluxes & $\mathrm{C}, \mathrm{N}$, water & $\mathrm{C}$, water \\
\hline C-input submodel & $\begin{array}{c}\mathrm{NPP}=\text { Photosynthesis } \\
\text { - Respiration }\end{array}$ & $\begin{aligned} \mathrm{NPP}= & \text { Photosynthesis } \\
& - \text { Respiration }\end{aligned}$ \\
\hline No. Tree C pools & 10 & 3 \\
\hline No. Tree N pools & 10 & 0 \\
\hline $\begin{array}{l}\text { No. Soil pools } \\
\text { (C, N, SOM, microbes) }\end{array}$ & 10 & 4 \\
\hline No. Surface litter pools & 3 & 0 \\
\hline
\end{tabular}

approaches that were labelled as Tier 1 to Tier 3 . Tiers 1 and 2 are methods that are based on forest volume statistics converted to carbon stocks using biomass expansion factors. Jalkanen et al. [6] in this issue discuss estimation of these factors for Sweden. Tier 3 methods as defined by Penman et al. [14] include process based models of forest growth. Such mathematical models of growth capture our understanding of how the carbon cycle operates but for the output from models to be believable they must be based on good field data. Here we describe two different approaches using data for Europe.

In the first approach an ecosystem model with little complexity is parameterized i.e. the value of its parameters are chosen, from the parameters of site specific growth models from a range of geographical locations. These site-specific models had previously been optimized to describe forest growth for its location. The ecosystem model is then used to describe the effect of temperature and carbon dioxide variation in time and space on forest growth and carbon exchange throughout Europe at multiple locations on a grid. Forest area and age structure from industry data were combined with the basic ecosystem model to provide country and regional totals for carbon exchange. Further information on the site-specific models and a comparison with other approaches using other ecosystem models are given by Kramer and Mohren [9].

In the second approach a complex forest growth model was directly parameterised for 22 specific locations in Europe. This model included the effect of many more variables e.g. nitrogen deposition, than the ecosystem model which allowed a more detailed assessment of the relative importance of the variables and of source of uncertainty.

Characteristics of the two models are compared in Table I.

\section{CASE STUDY 1: THE EUROBIOTA FOREST SYSTEM MODEL}

\subsection{The model}

The EuroBiota forest ecosystem model primarily describes the effect of changing temperature and atmospheric carbon dioxide concentration on productivity. The model is based on the work of Wang and Polglase [21]. They described the structure of a carbon cycle model in some detail and presented results of applying it to uniform age forest with characteristics and climate appropriate to three different biomes. Their treatment of soil respiration used the method of Jenkinson [7] within which turnover is influenced by three variables: temperature, soil moisture and cation exchange capacity of the soil. Wang and Polglase [21] assumed all areas of each biome had the same climate, plant and soil conditions but here we wish to consider how geographical variation of these conditions influences the carbon cycle. Additionally their model did not take into account spatial or temporal variation in soil moisture. The model concepts of Wang and Polglase [21] were therefore developed further to construct EuroBiota within which the influence of geographical variation in weather, the coverage of evergreen and deciduous forest at different locations and time series of afforestation is explicitly taken into account. The soil water balance was calculated on a daily time step using a two-layer model based upon the four-root-layer model of Ragab et al. [15]. Two links between carbon and moisture were written into Eurobiota. Soil moisture from the water balance model was used as an influence on soil carbon turnover in the carbon cycle model and canopy conductance from the carbon modelled controlled forest transpiration in the water model.

The overall structure of EuroBiota model is shown in Figure 1a and the carbon pools and fluxes in more detail in Figure 1b. The model has 7 state variables for carbon and about 40 parameters.

For application to European forests the model was run for each of about 4000 land locations on a $0.5^{\circ} \times 0.5^{\circ}$ grid across the region. The input data for each cell or groups of cells were used as follows. The basic scale of application for the model was for each $0.5^{\circ} \times 0.5^{\circ}$ latitude by longitude grid cell covering land in Europe between $34^{\circ} \mathrm{N}, 25^{\circ} \mathrm{W}$ to about $72.5^{\circ} \mathrm{N}, 36^{\circ} \mathrm{E}$.

A baseline daily pattern of weather was developed from the mean monthly climatology of the Climate Research Unit for the period 1961 to 1990 and the daily weather generator of Friend et al. [4]. This daily pattern has maximum and minimum air temperature, water vapour pressure deficit, solar radiation and precipitation and was assumed to apply for each year from 1860 to 2100 .

The effect of changing air temperature was described using a version of the data of the analysis of HADCM2 GCM output (at decadal scale) and CRU 1901-1995 climate data gridded to the $0.5^{\circ}$ cell size required by EuroBiota. This gave monthly temperature anomalies for each cell for each year from 1830 to 2100 with reference to the 1961 to 1990 baseline weather pattern.

Changes in carbon dioxide concentration throughout Europe followed the IS92a emission scenario and are as estimated by University of Bern for the IPCC Second Assessment Report. 
(a)

CARBON (BIOTA)

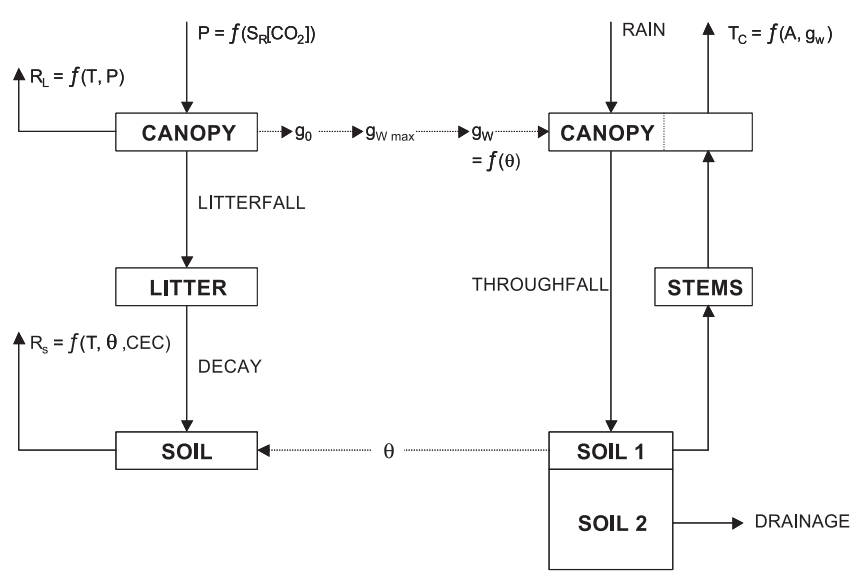

(b)

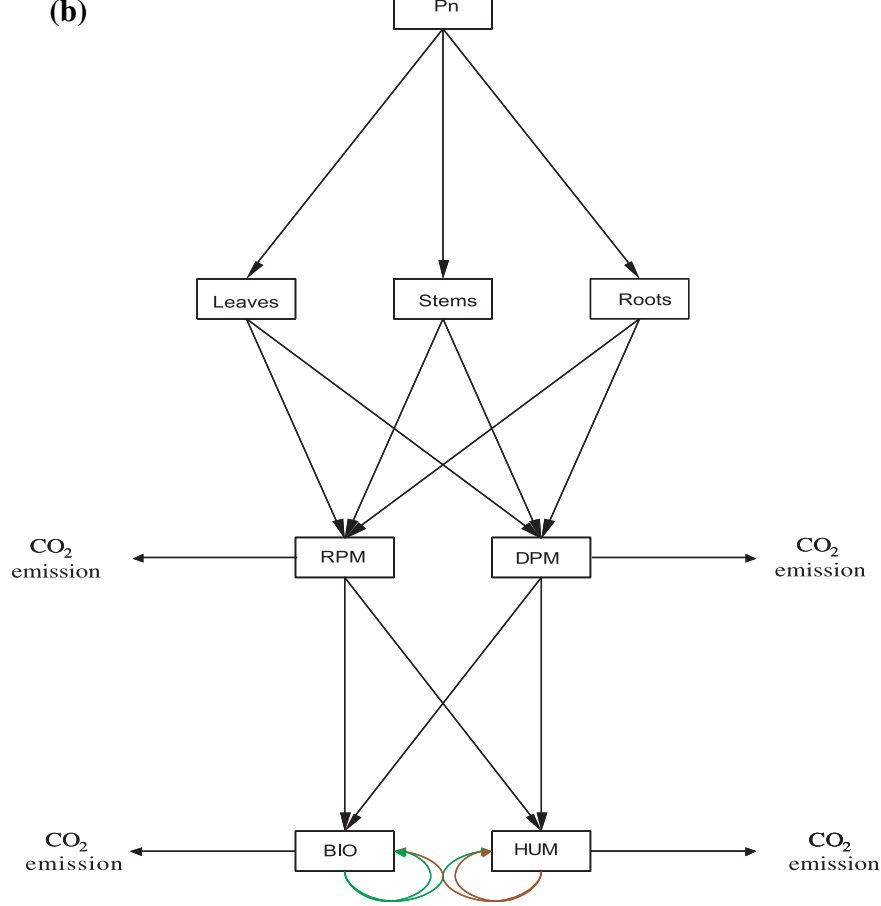

Figure 1. (a) Structure of the EuroBiota model showing links between carbon and water sub-models. $P$ is photosynthesis, $S_{R}$ is solar radiation, $T$ is temperature, $\theta$ is soil moisture content, $C E C$ is cation exchange capacity of soil, $g$ is canopy conductance, $T_{C}$ is transpiration, $A$ is net radiation. (b) Carbon pools and flows in the EuroBiota model. $P n$ is the net primary productivity. The seven other blocks represent the stock of carbon in leaves, stems, roots, recalcitrant plant matter (RPM) and decomposable plant matter (DPM) in litter or soil, biological (BIO) and humic (HUM) material in the soil. The litter and soil carbon pools are as defined by Jenkinson [7].

The location and area of forests were estimated from the USGS/IGBP-DIS Global Land Cover Characteristics $1 \mathrm{~km}$ scale data projected to latitude/longitude and gridded into $0.5^{\circ}$ $\times 0.5^{\circ}$ cells. Conifer and deciduous forests are distinguished. Bio-Climatic zones (Boreal, Temperate and Mediterranean) were also defined.

For each Bio-Climatic zone the physiological parameters relevant to European evergreen and deciduous forests were selected from the results from LTEEF II process-based models (Gotilwa, Hydrall, Forgro etc.) and from the ECOCRAFT Database [10]. Appropriate soil characteristics (clay content, rooting and overall depth) for each zone were chosen from the Global Environment Database [22]. For each country the age structure of forests was taken from the EFISCEN database and model. International boundaries were taken from ESRI Arcworld.

EuroBiota was run for European forests in 3 stages. (1) The carbon pools were initialised with effectively zero value and 1860 weather and carbon dioxide conditions assumed for each subsequent year and the model run to equilibrium carbon stocks. (2) Using these equilibrium tree and soil carbon stocks as new starting values the model was rerun with changing temperature and carbon dioxide for the years from 1860 to 2100 . (3) To assess the effect on productivity of the different age structure in different countries, and for times in the future, this transient run was recalculated, but in each country all forests had a simulated felling and replanting in the year indicated by the average age of forest for the year under consideration. The average of forest age for each country was calculated from the distribution of ages used in the EFISCEN model. For 1990 the EFISCEN base data was used and for later years the age distribution predicted by the Business As Usual Scenario was taken. This felling and replanting was modelled by removing in the appropriate year all stem carbon from the model and transferring leaf and root carbon to the litter pools. The forest was then forced to re-establish. The result of this approach is that productivities will be different in different countries, not only due to local weather conditions, but also due to the stage of recovery that the model forest has reached since the simulated felling/regrowth.

Here we describe results from this model when driven by rising atmospheric $\mathrm{CO}_{2}$ values and the pattern of change from 1860 to 2099 in mean monthly temperature for each $0.5^{\circ} \times 0.5^{\circ}$ cell in Europe. Carbon stocks in trees and soils are discussed as well as net primary productivity (NPP), soil respiration (Rs) and net ecosystem productivity (NEP) for individual countries, boreal, temperate and Mediterranean eco-climatic zones and Europe as a whole.

The carbon dioxide concentrations and the average annual temperature anomaly for Europe, implied by the GCM data used to drive EuroBiota, are shown in Figure 2. Temperature anomalies are actually applied in EuroBiota to the mean 1961 to 1990 daily climatology for each month in each separate $0.5^{\circ}$ cell separately. An illustration of the climatology is given in Figure 3 for a representative cell for each of the boreal, temperate and Mediterranean eco-climatic zones. 

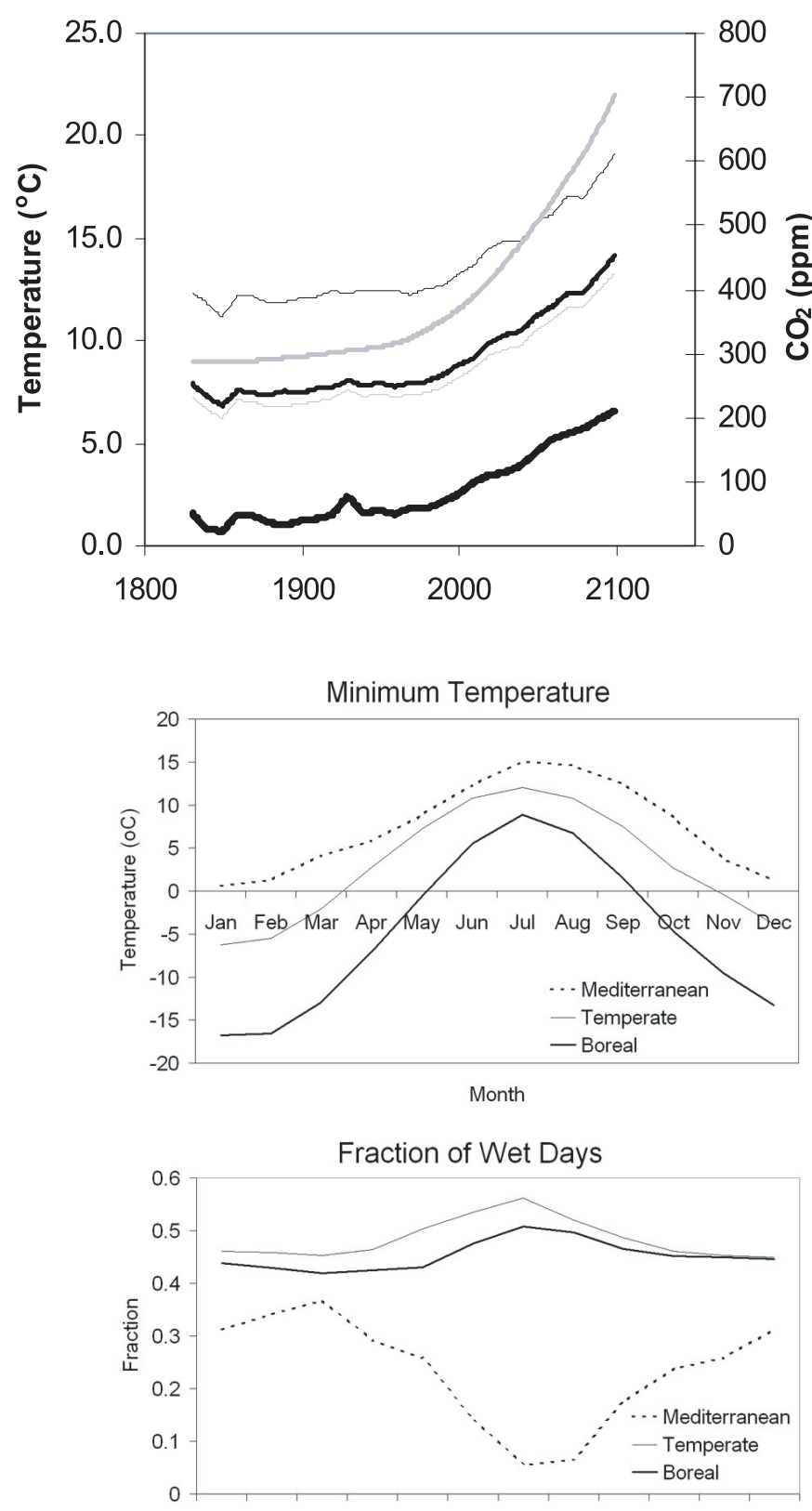

Jan Feb Mar Apr May Jun Jul Aug Sep Oct Nov Dec

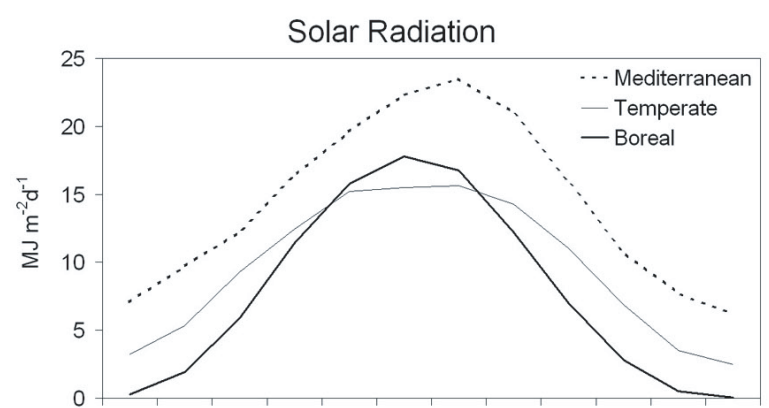

Jan Feb Mar Apr May Jun Jul Aug Sep Oct Nov Dec
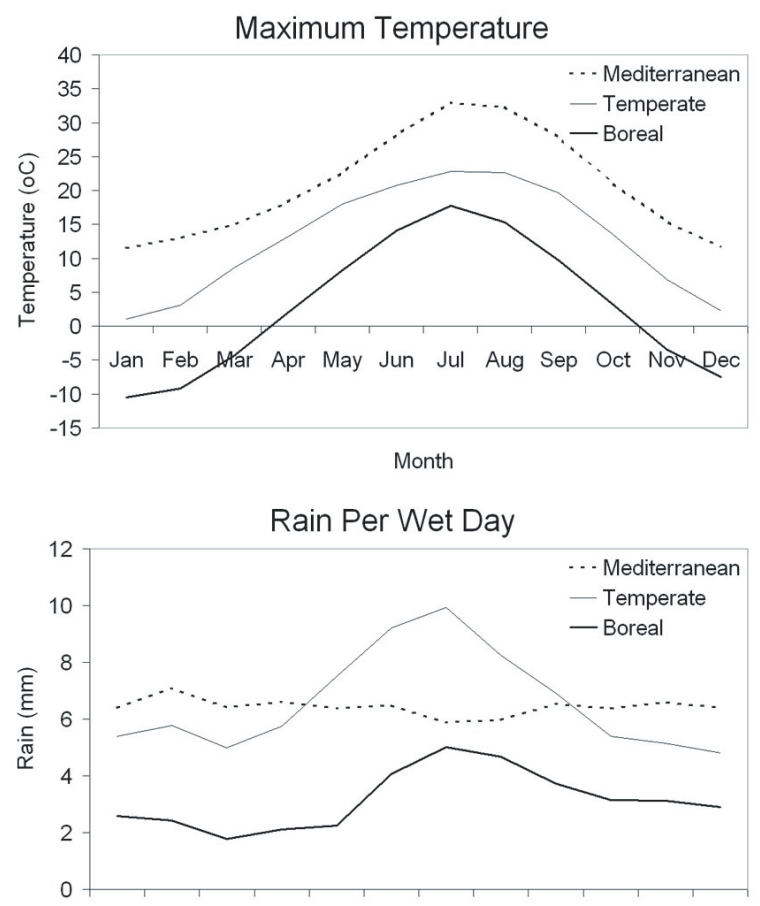

Jan Feb Mar Apr May Jun Jul Aug Sep Oct Nov Dec

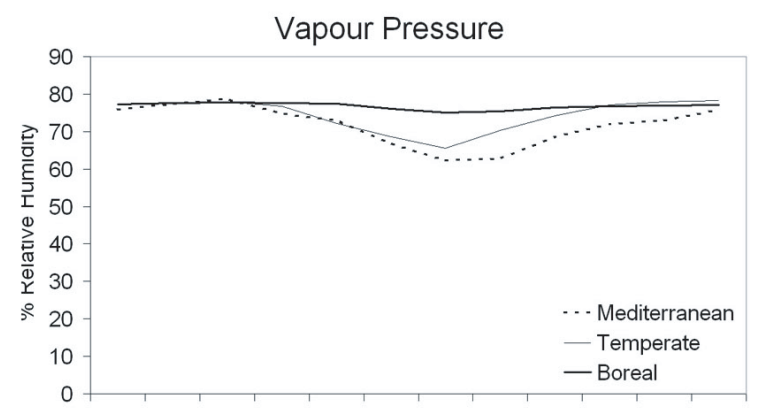

Jan Feb Mar Apr May Jun Jul Aug Sep Oct Nov Dec Month

Figure 3. Mean 1960 to 1989 climatology of cells representative of boreal (Lat $66.0^{\circ}$, Long. $\left.19.0^{\circ}\right)$, Temperate $\left(\right.$ Lat. $48.0^{\circ}$, Long. $\left.13.0^{\circ}\right)$, Mediterranean (Lat. $38.0^{\circ}$, Long. $-4.0^{\circ}$ ). 


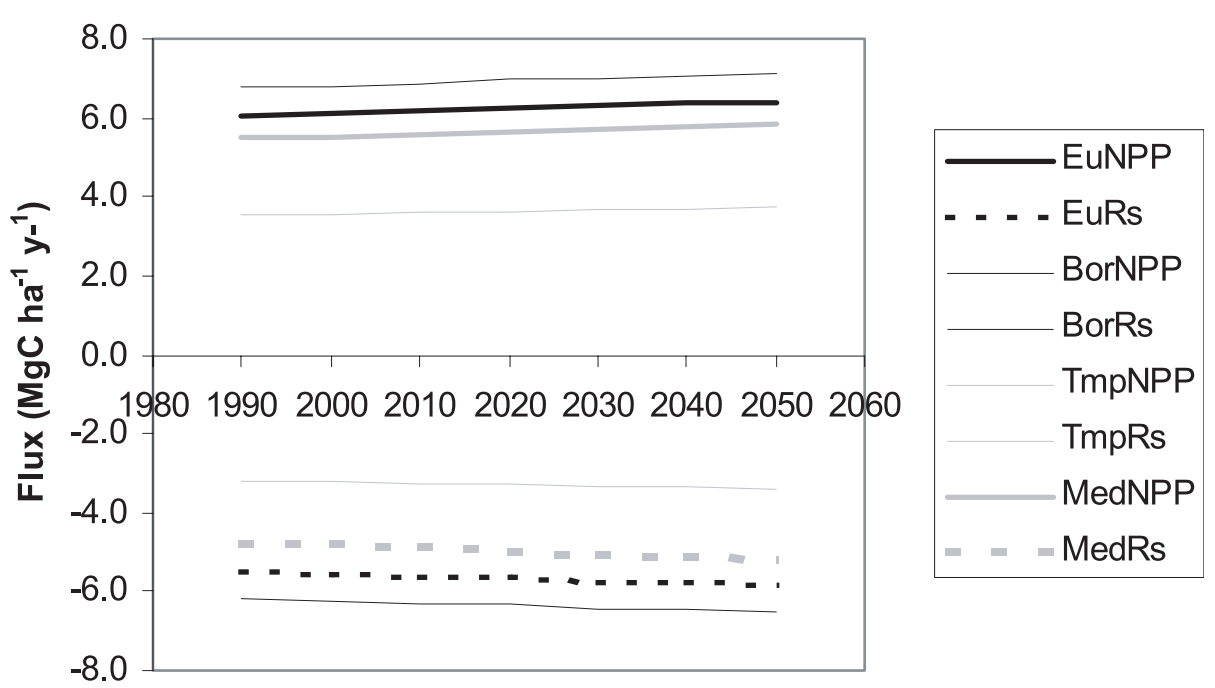

Figure 4. Productivity of European forest ecosystems from EuroBiota model for decades from the 1990s to the 2050s (abbreviations in legend text as in Fig. 2 and Tab. II).

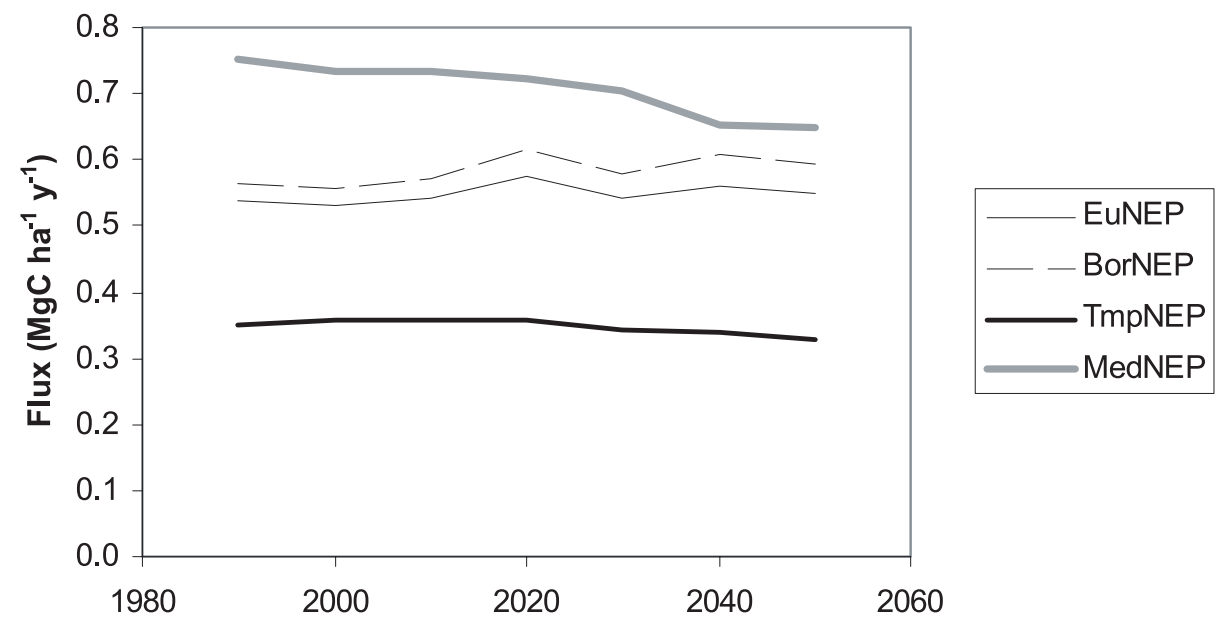

Figure 5. Net Ecosystem Productivity from EuroBiota model for European eco-climatic zones (abbreviations in legend text as in Fig. 2 and Tab. II).

\subsection{EuroBiota results}

The productivity of the forests of each eco-climatic zone (boreal, temperate, Mediterranean) of Europe as estimated by the EuroBiota model are presented in Figure 4 for Net Primary Productivity (NPP) and Soil Respiration (Rs) and Figure 5 for Net Ecosystem Productivity (NEP). The weighted averages for all of Europe are also shown.

The estimates of NEP (Fig. 5) show an overall increase in carbon uptake rate per unit area by European forest in the period from 1990 to 2050. This overall increase is however predominantly due to increases in the boreal zone whilst forests in both the temperate and Mediterranean zones have been estimated to have a reducing uptake rate per area of carbon. The contribution of changes in NPP and Rs in the different zones to the NEP changes is better shown in Table II. We can see that in the boreal zone NPP increases more than Rs which results in the increase in NEP of Figure 5, in the temperate zone an increase in NPP is offset by a larger increase in Rs and in the Mediterranean zone a fairly large increase in NPP is heavily offset by the increase in Rs producing the large reduction in NEP.

These changes are likely to be due to the relative response to differing changes of temperature in the trees and soils of the three zones. In the Mediterranean zone the increase in temperature has caused a relatively greater increase in turnover of soil carbon compared to other zones and to the increase in productivity. It should be noted here that the soil carbon turnover model in EuroBiota has four separate compartments each with individual rate constants (ranging from days to many decades) that depend on temperature. It is therefore not influenced by problems associated with assumption in some other studies where a single soil carbon component has the effect of temperature on the rate for carbon turnover determined by short-term experiments. 
Table II. Changes predicted by EuroBiota in forest Net primary productivity (NPP), soil respiration (Rs) and Net Ecosystem Productivity (NEP) between 1990 and 2050 in each of the three European eco-climatic zones compared to the European average ("Eu" - Europe, "Bor" Boreal, "Tmp" - Temperate, "Med" - Mediterranean).

\begin{tabular}{lcccccccc}
\hline $\mathrm{MgC} \mathrm{ha}^{-1} \mathrm{y}^{-1}$ & EuNPP & EuRs & BorNPP & BorRs & TmpNPP & TmpRs & MedNPP & MedRs \\
\hline 1990 & 6.06 & -5.52 & 6.76 & -6.19 & 3.53 & -3.18 & 5.50 & -4.75 \\
2050 & 6.41 & -5.86 & 7.14 & -6.55 & 3.74 & -3.41 & 5.84 & -5.19 \\
Change in NPP or Rs & 0.35 & -0.33 & 0.38 & -0.35 & 0.21 & -0.23 & 0.34 & -0.44 \\
Change in NEP & & 0.01 & & 0.03 & & -0.02 & & -0.10 \\
\hline
\end{tabular}

Table III. Future changes in total carbon stock, Net primary productivity (NPP), soil respiration (Rs) and Net Ecosystem Productivity (NEP) in European ecosystems as predicted by EuroBiota. Forest area unchanged.

\begin{tabular}{lcc}
\hline & 1990 & 2050 \\
\hline Forest area $\left(\mathrm{km}^{2}\right)$ & 1250000 & 1250000 \\
Tree carbon stock $(\mathrm{TgC})$ & 17.6 & 18.7 \\
Soil carbon stock $(\mathrm{TgC})$ & 16.0 & 16.6 \\
NPP $\left(\mathrm{TgC} \mathrm{y}^{-1}\right)$ & 0.76 & 0.80 \\
NEP $\left(\mathrm{TgC} \mathrm{y}^{-1}\right)$ & 0.07 & 0.07 \\
$\operatorname{Rs~}\left(\mathrm{TgC} \mathrm{y}^{-1}\right)$ & -0.69 & -0.73 \\
\hline
\end{tabular}

The overall change in the stock of tree and soil carbon per unit area in the period 1990 to 2050 as predicted by EuroBiota is shown in Table III, assuming a fixed forest area intermediate in the range of forest areas available from different sources as described in Kramer and Mohren [9].

As the grid cell size $\left(0.5^{\circ}\right)$ is sufficiently small it was possibly to summarise the outputs of EuroBiota in terms of most European countries (except for a few cases where the country was too small or the model had computational problems). These data are presented in Table IV and mapped in Figure 6.

The country data can also be used to show the effect of latitude on productivity. For a subset of the countries in Table IV the mean net ecosystem productivity of the cells falling within Their Boundaries In 1990 Was Calculated. These Values Are Plotted against the latitude of the centroid of the country in Figure 7. NEP becomes less at higher latitude but the effect is confused by the effect of the different age structure of the forests in each country. An estimate of relative productivity without the effect of age structure across Europe in 1990 can be obtained by using the output from EuroBiota at stage 1 of the sequence described above. These data describe the carbon flows in even aged coniferous and deciduous forests having grown to equilibrium in the climate since 1860 . The data for this situation is shown for Net Ecosystem Productivity and Net Primary Productivity is presented in Figure 8.

\subsection{EuroBiota case study: Summary}

The calculations of EuroBiota show the broad trend in productivity across Europe at different periods. The simplicity of the model precludes much detailed analysis of the relative importance of different environmental variables on productivity. Changes with time only take into account changes in temperature
Table IV. Future change in Net Ecosystem productivity (NEP) of forest ecosystems in European countries as estimated by EuroBiota. These estimates are of $\mathrm{MgC} \mathrm{ha}{ }^{-1} \mathrm{y}^{-1}$ and hence do not include effects of expansion in forest area but do include the effect of changing age structure as predicted in the EFISCEN "Business as Usual" scenario.

\begin{tabular}{|c|c|c|c|}
\hline Flux $\mathrm{MgC} \mathrm{ha}^{-1} \mathrm{y}^{-1}$ & NEP 1990 & NEP 2050 & Change \\
\hline Albania & 1.39 & 0.81 & -0.58 \\
\hline Austria & 0.08 & 0.14 & 0.07 \\
\hline Belgium & 0.74 & 0.82 & 0.08 \\
\hline Bosnia & 0.14 & 0.20 & 0.06 \\
\hline Bulgaria & 0.12 & 0.17 & 0.05 \\
\hline Belarus & 0.04 & 0.12 & 0.08 \\
\hline Croatia & 1.12 & 0.81 & -0.31 \\
\hline Czech Republic & 0.66 & 0.50 & -0.16 \\
\hline Denmark & 0.70 & 0.45 & -0.25 \\
\hline Estonia & 0.21 & 0.27 & 0.06 \\
\hline Finland & 1.05 & 1.13 & 0.08 \\
\hline France & 0.80 & 0.90 & 0.10 \\
\hline Germany & 0.55 & 0.47 & -0.08 \\
\hline Greece & 0.17 & 0.20 & 0.04 \\
\hline Hungary & 1.05 & 0.74 & -0.32 \\
\hline Iceland & 0.17 & 0.24 & 0.08 \\
\hline Ireland & 0.49 & 0.30 & -0.19 \\
\hline Italy & 1.27 & 0.95 & -0.32 \\
\hline Latvia & 0.13 & 0.21 & 0.08 \\
\hline Lithuania & 0.10 & 0.15 & 0.06 \\
\hline Macedonia & 1.35 & 1.05 & -0.30 \\
\hline Netherlands & 0.10 & 0.16 & 0.07 \\
\hline Norway & 0.93 & 0.92 & -0.01 \\
\hline Poland & 0.61 & 0.51 & -0.10 \\
\hline Romania & 0.86 & 0.61 & -0.25 \\
\hline Russia & 0.24 & 0.24 & 0.01 \\
\hline Slovakia & 0.83 & 0.67 & -0.16 \\
\hline Slovenia & 0.73 & 0.71 & -0.03 \\
\hline Spain & 0.14 & 0.25 & 0.11 \\
\hline Sweden & 0.21 & 0.23 & 0.02 \\
\hline Switzerland & 0.33 & 0.27 & -0.07 \\
\hline Turkey & 0.17 & 0.24 & 0.08 \\
\hline Ukraine & 0.03 & 0.14 & 0.12 \\
\hline United Kingdom & 0.72 & 0.50 & -0.22 \\
\hline
\end{tabular}




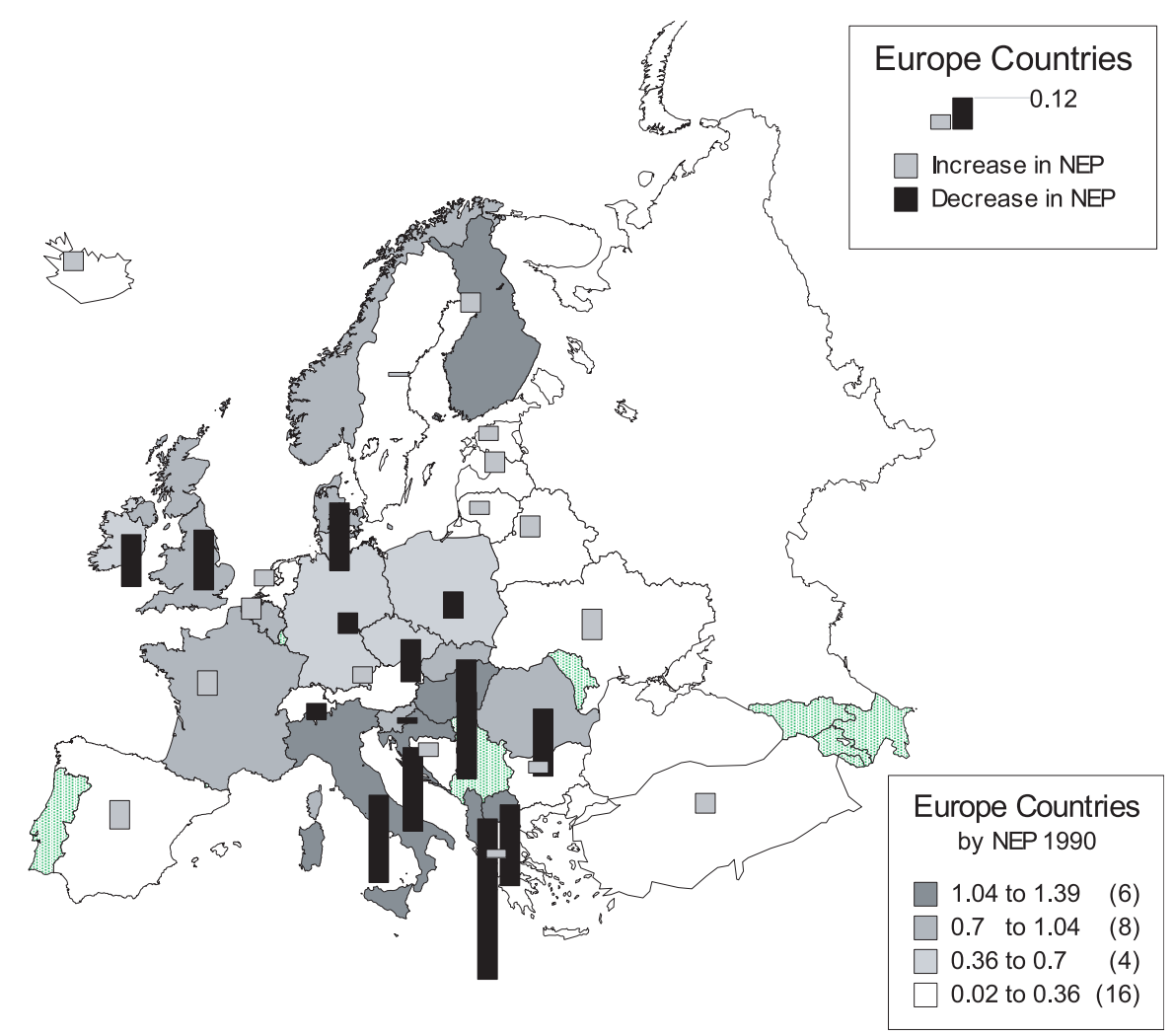

Figure 6. Net Ecosystem Productivity (NEP) $\left(\mathrm{MgC} \mathrm{ha}^{-1} \mathrm{y}^{-1}\right)$ in 1990 and change predicted by 2050 by EuroBiota model of ecosystem productivity and EFISCEN 'Business as Usual' production scenario. (Countries marked with stippled shading have no data or the forest area data caused computational difficulties.)

and carbon dioxide concentration whilst the trend with latitude for a specific year will be a combination of temperature with other climate variables. In addition the model does not include any assessment of the nitrogen cycle or how it has been affected by nitrogen pollution. In the next section a different model and approach is described to address some of these issues.

\section{CASE STUDY 2: PROJECT RECOGNITION}

\subsection{The project}

Recent studies have shown that many forests across Europe have started to grow faster during the second half of the 20th century [16]. The pattern of growth acceleration has not been homogeneous: sites in Scandinavia showed smaller increases in growth rate than Central-European sites, but there were some sites in Germany and Austria where forest growth had not changed much either [16]. Project RECOGNITION was initiated in 1999 to identify the causes for the observed changes in forest growth, and to assess whether the growth trends would continue. Twenty four project partners were involved in 14 countries. Most of the partners focused on collecting and statistically analysing data on trees, soils and climate, and four partners studied the problem by means of different processbased models $[8,11]$. Here we focus on the process-based

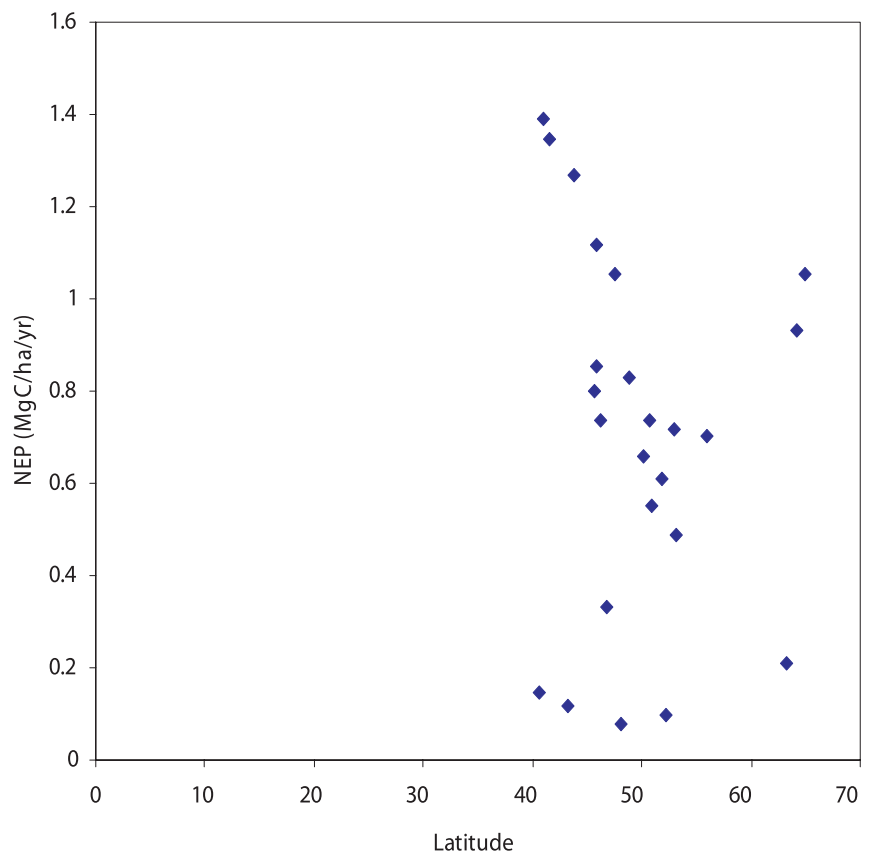

Figure 7. Variation of mean country Net Ecosystem Productivity with latitude of centroid of country including the effect of different age structure. 


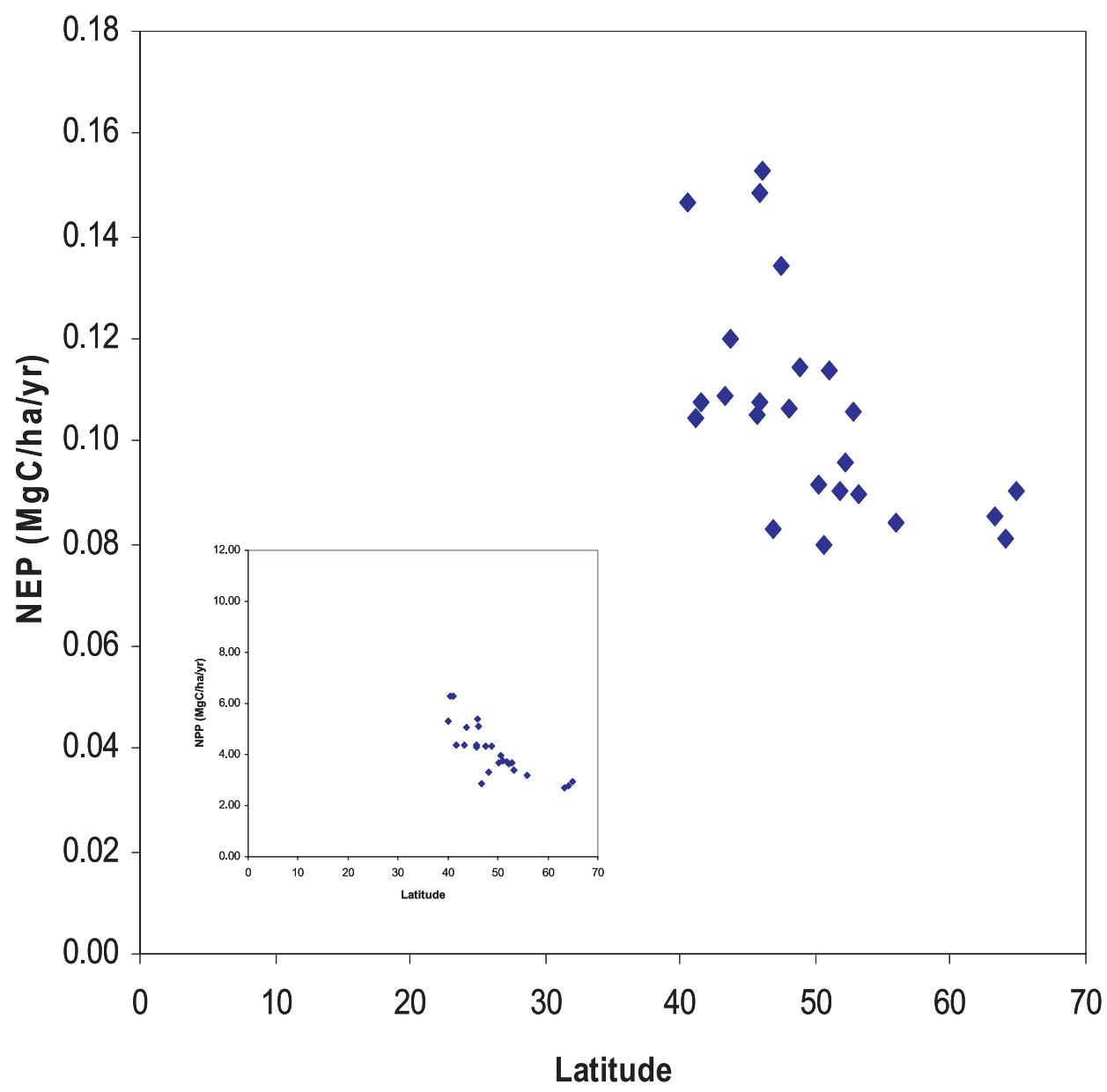

Figure 8. Variation of mean country Net Ecosystem Productivity with latitude of centre of country excluding the effect of different age structure. Variation of country mean Net Primary Productivity is inset. modelling, and particularly on the results acquired by means of the Edinburgh Forest Model (EFM) [17-19], which represented the biogeochemical fluxes through the forest in greatest detail. The EFM has 261 parameters and 50 state variables, representing tree volume and height as well as pools of water and various $\mathrm{C}$ - and $\mathrm{N}$-containing materials in soil and tree organs.

The process-based modelling in RECOGNITION focused on 22 sites across Europe (Fig. 9), 9 planted to Norway spruce (Picea abies L.) and 13 to Scots pine (Pinus sylvestris L.) [11]. The twenty-two sites were selected because they represented important conifer growing areas across Europe, at latitudes ranging from 48.29 to $67.25^{\circ} \mathrm{N}$, and because data on growing conditions were available for the sites. The sites varied in carbon content of the top $50 \mathrm{~cm}$ of soil from 37000 to $310000 \mathrm{~kg}$ $\mathrm{C} \mathrm{ha}^{-1}$, and in nitrogen content from 1100 to $10400 \mathrm{~kg} \mathrm{~N} \mathrm{ha}^{-1}$. Average yearly temperature (1975-1990) ranged from $-0.6^{\circ} \mathrm{C}$ at the most northerly site Kolari $\left(67.15^{\circ} \mathrm{N}\right)$ to $10.0^{\circ} \mathrm{C}$ at three sites in South-eastern Germany.

Process-based modelling requires input scenarios that define the time courses of the external conditions that are input to the models. In RECOGNITION, the scenarios needed to cover three environmental factors, changes in which had been put forward as possible causes of the observed acceleration of forest growth: weather conditions, atmospheric concentration

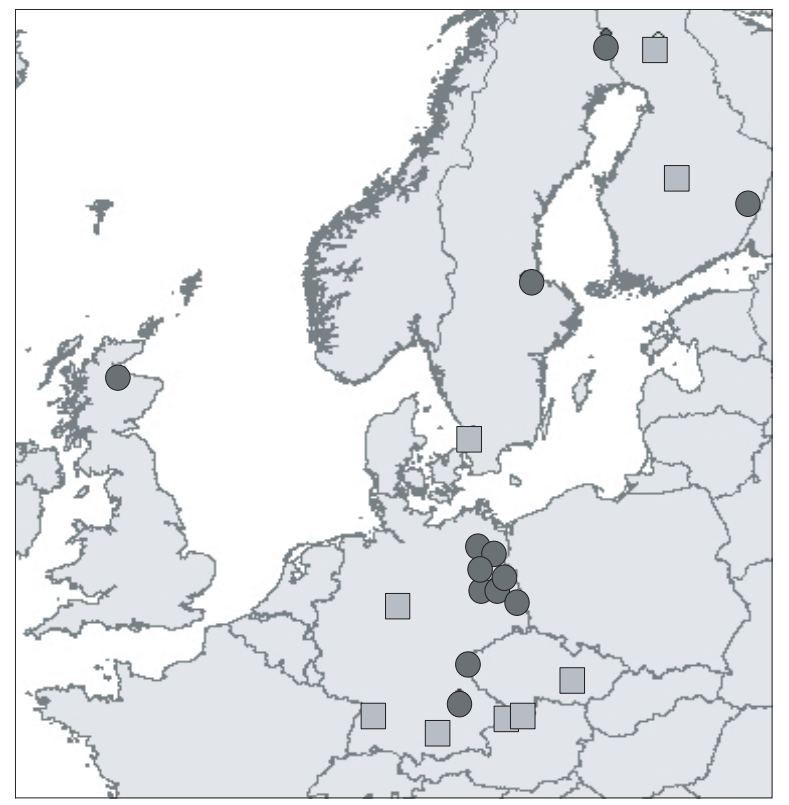

Figure 9. Sites used in project RECOGNITION for process-based modelling. Squares: Norway spruce $(n=9)$, Circles: Scots pine $(n=13)$. 
of $\mathrm{CO}_{2}$ and $\mathrm{N}$-deposition. Two types of scenarios were defined for each of the 22 sites: "reference scenarios" and "environmental change scenarios" [11]. In simulations using the reference scenarios, forest growth was simulated for a period of 80 years but with $\mathrm{CO}_{2}$ and $\mathrm{N}$-deposition kept at the values they had in 1920, and weather conditions cycling through values for 1920-1927. In contrast, the environmental change scenarios represented the changes actually observed between 1920 and 2000 in one or more of the environmental factors. Atmospheric $\mathrm{CO}_{2}$ concentration increased from 302 to $370 \mu \mathrm{mol} \mathrm{mol}^{-1}$, with little variation between sites. N-deposition increased from a 22 site average of $4.2 \pm 1.5$ (SD across sites) $\mathrm{kg} \mathrm{N} \mathrm{ha}^{-1} \mathrm{y}^{-1}$ in 1920 to an average $\mathrm{N}$-deposition over the whole period 1920-2000 of $10.5 \pm 5.2 \mathrm{~kg} \mathrm{Nha}^{-1} \mathrm{y}^{-1}$, i.e. an increase of about $150 \%$. Temperature increased $0.52 \pm 0.24^{\circ} \mathrm{C}$ from its $1920-1927$ reference level, but other weather variables changed little. Analysis of the differences in simulated forest growth between reference conditions and environmental change allowed identification of the major growth-changing factors.

So far, most of the analysis of the results of the process-based modelling study in RECOGNITION has focused on the identification of the key environmental drivers, on the comparison between the four different process-based models, and on comparison between process-based modelling and empirical analysis $[12,13]$. Here, we will analyse the results more deeply, focusing on the results for carbon stocks and biogeochemical cycling, and on how they may explain the differences between sites in growth and in growth response to the changing environment.

\subsection{RECOGNITION: Simulations of changes in growth and carbon stocks}

Simulations using reference scenarios for the environmental conditions confirmed common observation in that average net primary productivity over 80 years of forest growth (NPP; t DM $\mathrm{ha}^{-1} \mathrm{y}^{-1}$ ) decreased with latitude (Fig. 10, top left panel). The correlation was well explained by differences between sites in temperature (affecting both growing season duration and within-season growth rate) and in soil fertility (Fig. 10, left column, middle and bottom panel). Both temperature and soil fertility decrease with latitude, the latter partly because of differences in $\mathrm{N}$-deposition. The simulations using complete environmental change scenarios (i.e. all of weather, $\mathrm{CO}_{2}$ and $\mathrm{N}$-deposition changing as observed between 1920 and 2000) showed increases in NPP on all 22 sites (Fig. 10, right column, top right panel) which suggests that the model was able to explain the observed changes in forest growth rate across Europe [16]. Like NPP itself, the change in NPP varied with latitude. NPP increased least at higher latitudes, although some lower-latitude sites showed little increase in NPP in response to environmental change (Fig. 10, top right panel). The latitudinal trend in NPP-change and the exceptional response of some Central European sites were in general agreement with the observations of Spiecker et al. [16]. The sensitivity of NPP to changes in the growing environment generally increased with temperature but decreased with soil fertility (Fig. 10, right column, middle and bottom panel).

\subsection{RECOGNITION: Simulations of changes in $\mathrm{C}$ - and $\mathrm{N}$-cycling}

The increase in NPP because of environmental change led to an increase in carbon stock in tree and soil at the end of the simulated 80-year growing periods (Fig. 11). The average increase in end-of-growing-period carbon stock was $4.3 \mathrm{~kg} \mathrm{C}$ $\mathrm{m}^{-2}$, corresponding to an average sink of $0.54 \mathrm{Mg} \mathrm{C} \mathrm{ha}^{-1} \mathrm{y}^{-1}$. Increased $\mathrm{N}$-deposition was identified as the major environmental factor causing the increase in $\mathrm{C}$-stock (Fig. 11). The carbon-sink of tree biomass increased more $\left(0.51 \pm 0.33 \mathrm{Mg} \mathrm{Cha}^{-1}\right.$ $\left.\mathrm{y}^{-1}\right)$ than that the soil carbon sink $\left(0.03 \pm 0.02 \mathrm{Mg} \mathrm{C} \mathrm{ha}^{-1} \mathrm{y}^{-1}\right)$. The nature of the sink, i.e. tree or soil, is of importance because tree biomass is removed in the form of forest products whereas soil carbon may represent a longer-lived sink. We therefore analysed the simulated effects on the flows of carbon through the system in more detail (Fig. 12, left column). C-cycling at reference growing conditions was characterised by an increase in tree carbon and a decrease in soil carbon during the 80-year growing period (Fig. 12, top left panel), but note that the simulations did not account for thinning, and both effects could further be negated by subsequent tree felling which would remove tree carbon and add to soil litter. Environmental change, either increased N-deposition by itself (Fig. 12, middle left panel) or all three changes combined (bottom left panel) increased tree carbon but did not proportionately increase the flow of tree litter to soil. This result was at first surprising, as litter production through senescence of leaves, branches and roots is of necessity dependent on the amount of source material present. However, further analysis of the model results showed that environmental change affected carbon allocation in the trees, with especially increased $\mathrm{N}$-deposition leading to a decrease in the amount of fine roots of $16-18 \%$. These model results reflect the functional equilibrium between roots and shoot [1]. So, litter-C production is not enhanced significantly by environmental change because the biomass-pool with the highest turnover rate, i.e. fine roots, is decreased in size. These results emphasize the dangers of using simple linear carbon cycling in models in which any biomass increase leads to an equivalent increase in all flows between model components, including carbon-sequestration in soil. Neither EFM nor EuroBiota model adopts this approach because each treats the change in soil carbon as a balance between inputs from the plants and losses due to soil organic matter turnover.

The environmental effects on C-partitioning emphasise that changes in the $\mathrm{C}$-cycle are linked to, but not necessarily proportional to, concurrent changes in the $\mathrm{N}$-cycle. The default values for the major flows in the forest $\mathrm{N}$-cycle, under reference conditions, are shown in Figure 12 (top right panel). The lower panels show the response of the $\mathrm{N}$-cycle to increased $\mathrm{N}$-deposition alone and in combination with changes in weather and $\mathrm{CO}_{2}$. In contrast to the $\mathrm{C}$-cycle, environmental change does significantly increase the flow of litter-nitrogen from trees to soil. Taken together, this means that total litter production is not enhanced much but its quality, i.e. nitrogen content, is. These results are consistent with the findings of Hendricks et al. [5], who found fine root nitrogen content to increase markedly with soil nitrate availability in a study of 27 forests in the northern United States, and conjectured that this might enhance root decomposition and nitrogen cycling in the system. The higher 


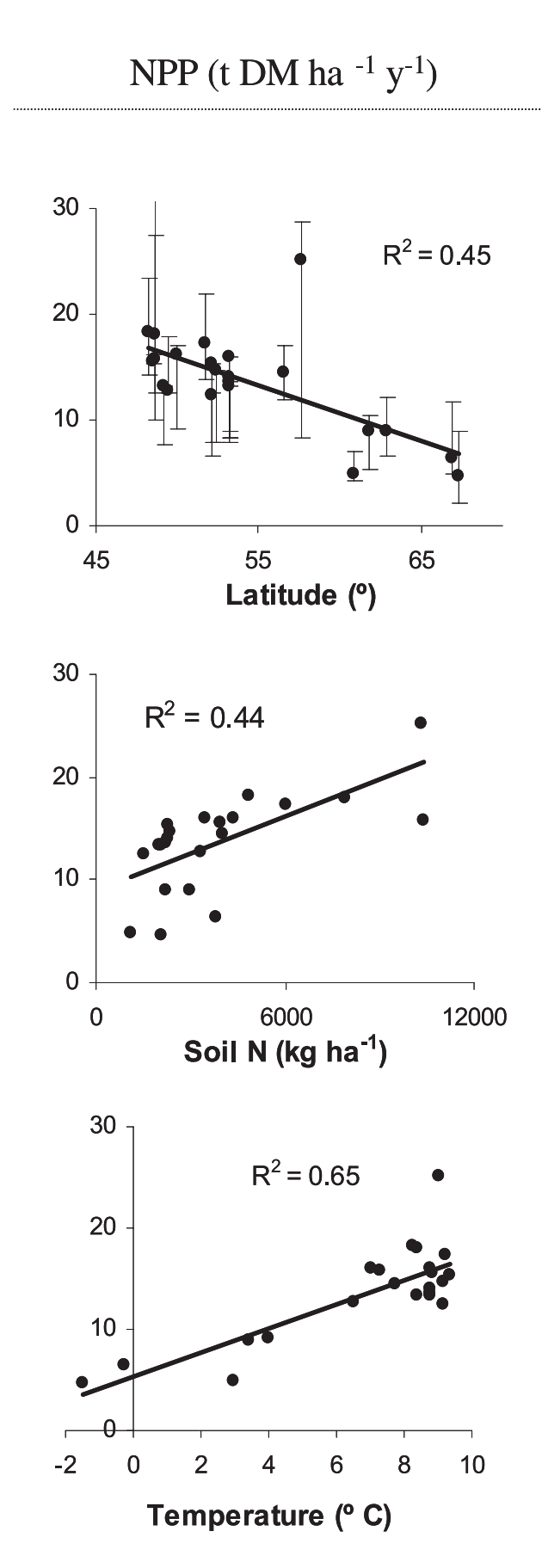

\section{Change in NPP $(\%)$}
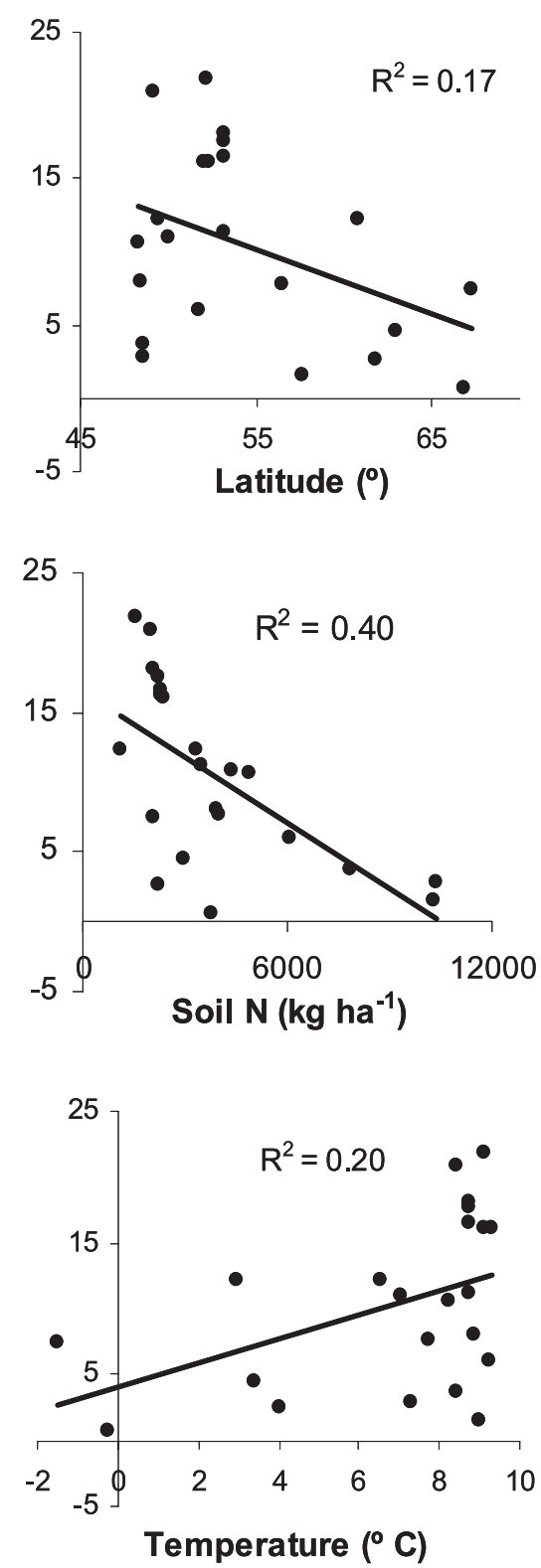

Figure 10. Simulation results from the Edinburgh Forest Model: NPP at 22 sites. Left column: $\mathrm{NPP}\left(\mathrm{tDM} \mathrm{Ha}^{-1} \mathrm{y}^{-1}\right)$; right column: changes in NPP (\%). The lines are linear regression lines of simulation results on site-variables: latitude, average yearly temperature (1975-1990) and soil N-content.

litter quality stimulates mineralization (as confirmed recently by Colin-Belgrand et al. [2]), so N-uptake by the trees is facilitated as well. In fact, the increase in the rate of $\mathrm{N}$-cycling between trees and soil is about four times as high as the increase in $\mathrm{N}$ deposition that triggered it in the first place (Fig. 12, bottom right panel). In summary, environmental change, particularly increased $\mathrm{N}$-deposition, triggers accelerated $\mathrm{N}$-cycling between trees and soil, mediated by production of litter at about normal rates but of higher quality, thereby sustaining high NPP.
The preceding analysis of the $\mathrm{N}$-cycle suggests that at sites where the soil-tree $\mathrm{N}$-cycle is already approaching a limit, and thus cannot be enhanced much further by N-deposition, NPP and forest $\mathrm{C}$-stock may not respond to even a strong increase in N-deposition. On such sites, N-leaching is more likely to increase than growth [3]. Returning to Figure 10, right column, we saw that environmental change indeed stimulated NPP less at fertile sites $\left(r^{2}=0.40\right)$. More importantly, soil fertility was a better predictor of response to environmental change, than 


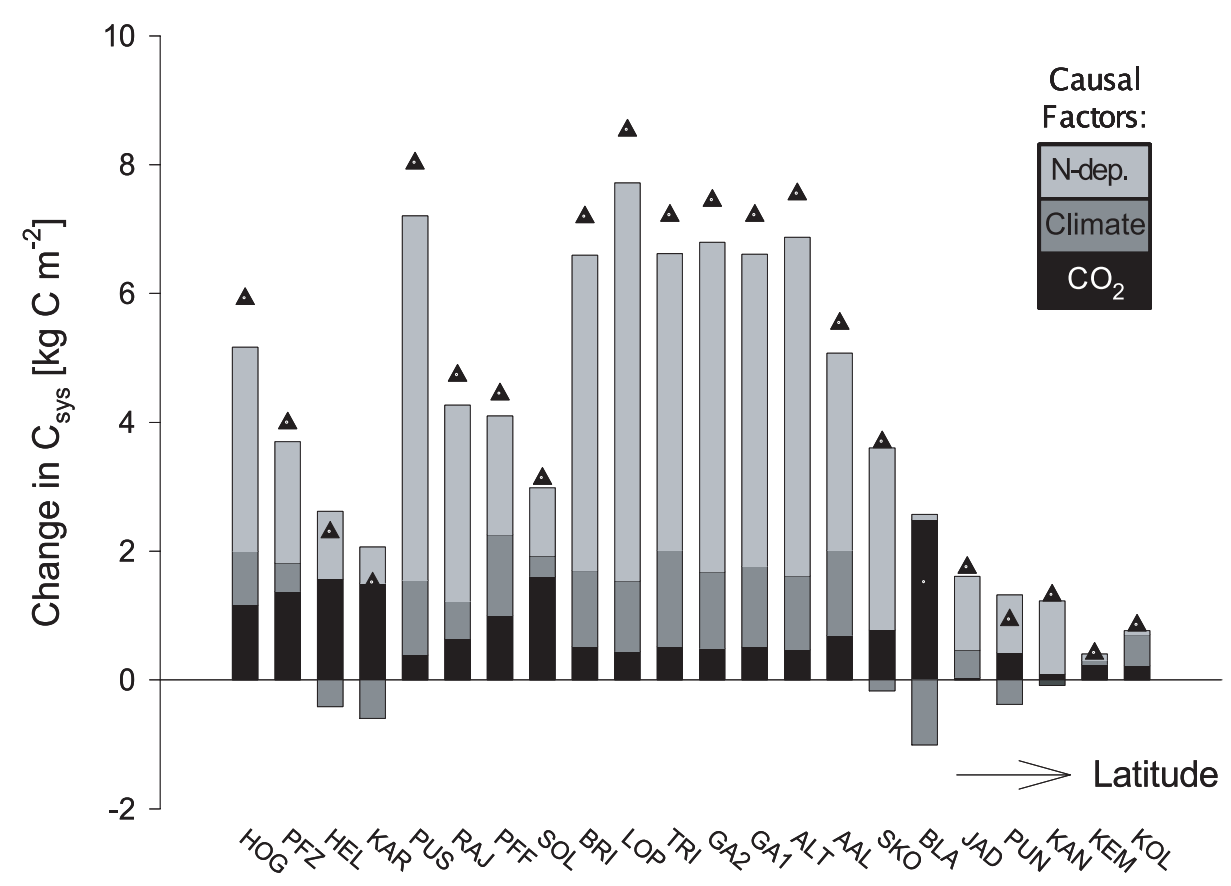

Figure 11. Simulation results from the Edinburgh Forest Model: Carbon stocks at 22 sites. Effects of changes in $\left[\mathrm{CO}_{2}\right]$, climate and N-deposition on carbon stocks in conifer forests at 22 sites across Europe between 1920 and 2000 . The bars show the effect of environmental conditions $\left(\mathrm{CO}_{2}\right.$, climate and N-deposition) on carbon stocks. Sites are ordered from lowest latitude (HOG = Höglwald, southern Germany, $\left.48.18{ }^{\circ} \mathrm{N}\right)$ to highest $\left(\mathrm{KOL}=\right.$ Kolari, northern Finland, $\left.67.15^{\circ} \mathrm{N}\right)$. Triangles indicate the cumulative effect of the three environmental changes, the combined effect of $\mathrm{CO}_{2}$, climate and $\mathrm{N}$ generally being slightly more than additive.

absolute or relative increase in $\mathrm{N}$-deposition itself $\left(r^{2}=0.21\right.$; $\left.r^{2}=0.25\right)$, even though $\mathrm{N}$-deposition was the major factor of environmental change (Fig. 11).

\subsection{RECOGNITION: Summary}

The simulations confirm the results of Spiecker et al. [16] in various ways: the growth enhancement itself, the lessincreased growth at high latitudes because of lower temperatures and lower rates of $\mathrm{N}$-deposition, and the small increase at some more southerly sites because of $\mathrm{N}$-saturation. The simulations suggested that the growth enhancement of European forests may not lead to equivalent increases in C-sequestration because: (1) the majority of the sink enhancement is in tree biomass rather than in possibly more stably sequestered soil components, (2) the fraction of tree biomass that does find its way to the soil is of high quality and can easily be decomposed.

\section{DISCUSSION}

The two case studies presented in this paper both addressed the impact of environmental change on the carbon stock in forests in different regions of Europe. However, the methods that were used differed strongly. Case study 1 applied a simple model, EuroBiota, which has, although similar in its philosophy for tracking carbon flow through the system, about seven times fewer parameters and state variables than the EFM model used in the second study. The use of different models dictated the way they were applied to the issue of environmental change impacts. The simple EuroBiota model is comparatively fast and could be applied on a high-resolution grid across Europe, with 4000 cells in total. The EFM model, on the other hand, is slow (current running time for an 80-year forest rotation is $7 \mathrm{~min}$ ) and data-demanding and was therefore only applied to 22 sites across Europe for which much quantitative information on soils, weather and forest management was available. Running speed is not the only determinant of the number of sites to which a model can be applied. The EFM model has detailed algorithms of the linkage between the carbon and nitrogen cycle and could therefore also be used to investigate the impact of change in atmospheric nitrogen deposition, which led to a doubling of the numbers of calculated scenarios per site.

In spite of the differences between the models and their application, it is still possible to compare the results of the two studies, in terms of identified latitudinal and temporal trends, and with regard to the identification of key environmental drivers. Both models were able to reproduce the negative correlation of latitude with forest productivity (NEP in EuroBiota, NPP in EFM) that has been observed, for example, by Valentini et al. [20]. The models also agreed in that they indicated a positive impact of elevated $\mathrm{CO}_{2}$ and climate change on forest carbon stock across Europe, at least until the present day. The models did differ in their assessment of the geographical distribution of the impact of environmental change e.g. EFM showed a greater increase in the past of C-stocks in Central Europe compared to EuroBiota. However this difference is explained by the presence of nitrogen deposition in EFM that 


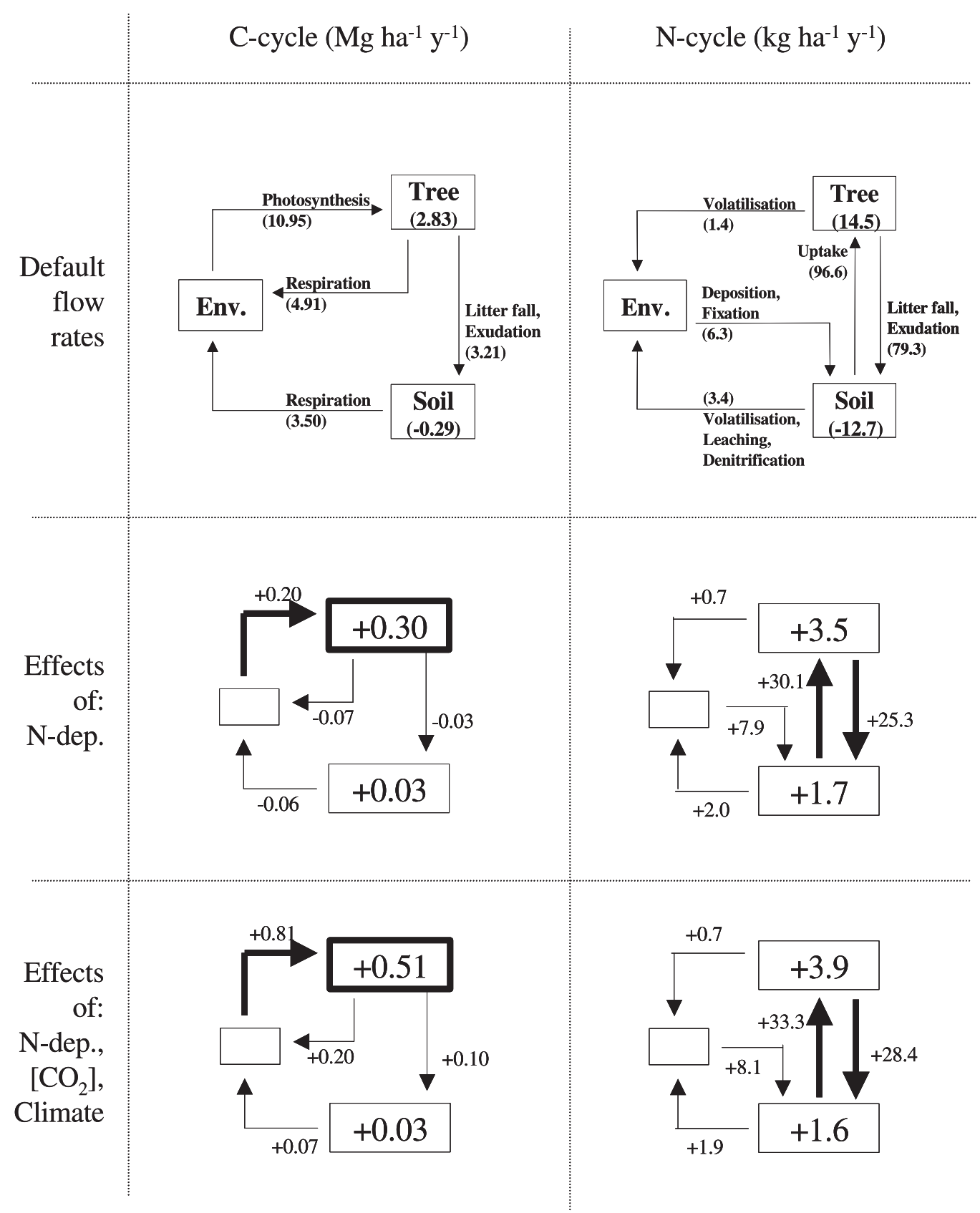

Figure 12. Simulation results from the Edinburgh Forest Model: the average yearly flow rates of carbon and nitrogen between trees, soil and environment during 80-year periods of simulated forest growth on 22 sites across Europe. Left column: C-cycle, right column: N-cycle. Top row: flow rates for simulations under reference (1920s) conditions. Second row: changes in flow rates, relative to the reference flows, because of increased atmospheric N-deposition. Bottom row: as second row but for changes in N-deposition, $\left[\mathrm{CO}_{2}\right]$ and weather.

had strong impact in central Europe. If we consider the future projections of the two models they both suggest the greatest response in higher latitudes because future nitrogen deposition is not expected to continue increasing. Moreover, both models showed a larger fractional increase in tree biomass than in soil organic matter. The underlying mechanism in both cases was that the stimulated flow of carbon into the soils, caused by stimulated tree growth, was partly offset by increased decomposition in the soils because of increases in soil temperature. Note that these differences in simulated behaviour between trees and soils show that EuroBiota, in spite of its simplicity, is like the EFM not a linear model.

Clearly, the results of the second study, using the EFM and only 22 sites, cannot be used to make any statements about the carbon stock of individual countries. However, the strength of the EFM-study lies in its larger range of environmental factors that could be examined. The EFM-study thus showed that the increases in European forest growth observed in recent decades 
[16], was due mainly to increased nitrogen deposition, with smaller contributions from elevated $\mathrm{CO}_{2}$ and climate change, EuroBiota did not show this effect of nitrogen deposition because it was restricted to these two latter factors. However, the EFM-study also indicated that the key drivers in future environmental changes are likely to be $\mathrm{CO}_{2}$ and climate change, thereby justifying the use of the simpler model for prediction.

The strength of the EuroBiota study lies in its high spatial resolution, and that of the EFM study in its more detailed consideration of environmental drivers, in particular nitrogen. As the strengths of each model correspond to relative weaknesses in the other, we feel that it is may be best to combine models of widely different levels of complexity in studies of environmental change, rather than just use one model.

\section{CONCLUSIONS FROM THE TWO STUDIES}

- Observations of increased forest growth across Europe were explained by analyses using a simple 40-parameter growth model, EuroBiota, and a complex 261-parameter forest ecosystem model, EFM.

- Both models showed that forest growth in many parts of Europe will have benefited from increased atmospheric $\mathrm{CO}_{2}$ concentrations and climate change, but only the EFM highlighted the role of enhanced N-deposition.

- Both models showed that carbon stocks are likely to have increased more in tree biomass than in soils.

- Unlike the EuroBiota and EFM models used here, linear models cannot be used to assess the different roles of standing biomass and soil organic matter in carbon sequestration.

- Simple dynamic models can be useful for broad assessment of regional variation in forest productivity, whereas complex dynamic models with many parameters can be used most easily for specific sites where detailed information is available for parameterisation.

- Complex models can consider a wider variety of environmental drivers and are therefore more useful for apportioning the effects of different environmental variables on productivity.

Acknowledgements: The EuroBiota work was funded by the EU under the Environment programme as project LTEEF-II (ENV4CT97-0577). Project RECOGNITION was funded by the EU under the FAIR programme, CT98-4124. We thank all our colleagues for data on model parameters, soil carbon and nitrogen and for discussion and collaboration regarding process-based modelling. Special thanks go to Deena Mobbs for formatting work with the manuscript.

\section{REFERENCES}

[1] Brouwer R., Functional equilibrium - Sense or nonsense? Neth. J. Agric. Sci. 31 (1983) 335-348.

[2] Colin-Belgrand M., Dambrine E., Bienaime S., Nys C., Turpault M.P., Influence of tree roots on nitrogen mineralization, Scand. J. Forest Res. 18 (2003) 260-268.

[3] Corre M.D., Beese F.O., Brumme R., Soil nitrogen cycle in high nitrogen deposition forest: Changes under nitrogen saturation and liming, Ecol. Appl. 13 (2003) 287-298.
[4] Friend A.D., Parameterisation of a global daily weather generator for terrestrial ecosystem modelling, Ecol. Model. 109 (1998) 121-140.

[5] Hendricks J.J., Aber J.D., Nadelhoffer K.J., Hallett R.D., Nitrogen controls on fine root substrate quality in temperate forest ecosystems, Ecosystems 3 (2000) 57-69.

[6] Jalkanen A., Mäkipää R., Ståhl G., Lehtonen A., Petersson H., Estimation of the biomass stock of trees in Sweden: comparison of biomass equations and age-dependent biomass expansion factors, Ann. For. Sci. 62 (2005) 845-851.

[7] Jenkinson D.S., The turnover of organic-carbon and nitrogen in Soil, Philos. Trans. R. Soc. Lond. Ser. B-Biol. Sci. 329 (1990) 361-368.

[8] Karjalainen T., Schuck A., Introduction, in: Karjalainen T., Schuck A. (Eds.), Causes and Consequences of Forest Growth Trends in Europe - Results of the RECOGNITION Project, Chapter 1, Leiden, Brill, Leiden (in press).

[9] Kramer K., Mohren G., Long-term effects of climate change on carbon budgets of forests in Europe, in: Final report of EU-funded project Long-term regional effects of climate change on European forests: impact assessment and consequences for carbon budgets (LTEEF-II, ENV4-CT97-0577) (2001).

[10] Medlyn B.E., Jarvis P.G., Design and use of a database of model parameters from elevated CO2 experiments, Ecol. Model. 124 (1999) 69-83.

[11] Oijen M.V., Ågren G., Chertov O. et al., Application of processbased models to explain and predict changes in European forest growth, in: Karjalainen T., Schuck A. (Eds.), Causes and Consequences of Forest Growth Trends in Europe - Results of the RECOGNITION Project, Chapter 3.2, Leiden, Brill, Leiden (in press).

[12] Oijen M.V., Ågren G., Chertov O. et al., Evaluation of past and future changes in European forest growth by means of four processbased models, in: Karjalainen T., Schuck A. (Eds.), Causes and Consequences of Forest Growth Trends in Europe - Results of the RECOGNITION Project, Chapter 4.4, Leiden, Brill, Leiden (in press).

[13] Oijen M.V., Prietzel J., Ågren G. et al., A comparison of empirical and process-based modelling methods for analysing changes in European forest growth, in: Karjalainen T., Schuck A. (Eds.), Causes and Consequences of Forest Growth Trends in Europe - Results of the RECOGNITION Project, Chapter 5.1, Leiden, Brill, Leiden (in press).

[14] Penman J.O., IPCC Good Practice Guidance for Land Use, LandUse Change and Forestry, IGES, Hayama, 2003.

[15] Ragab R., Finch J., Harding R., Estimation of groundwater recharge to chalk and sandstone aquifers using simple soil models, J. Hydrol. 190 (1997) 19-41.

[16] Spiecker H. et al., Growth Trends in European Forests, EFI Research Report 5, Springer, 1996.

[17] Thornley J.H.M., A transport-resistance model of forest growth and partitioning, Ann. Bot. 68 (1991) 211-226.

[18] Thornley J.H.M., Cannell M.G.R., Nitrogen relations in a forest plantation-soil organic-matter ecosystem model, Ann. Bot. 70 (1992) 137-151.

[19] Thornley J.H.M., Cannell M.G.R., Temperate forest responses to carbon dioxide, temperature and nitrogen: A model analysis, Plant Cell Environ. 19 (1996) 1331-1348.

[20] Valentini R., Matteucci G., Dolman A.J. et al., Respiration as the main determinant of carbon balance in European forests, Nature 404 (2000) 861-865.

[21] Wang Y.P., Polglase P.J., Carbon balance in the tundra, Boreal forest and humid tropical forest during climate-change - Scaling-up from leaf physiology and soil carbon dynamics, Plant Cell Environ. 18 (1995) 1226-1244.

[22] Webb R.S., Rozenweig C.E., Levine E.R., Global Soil Particle Size Properties. Digital raster data on a 1 degree geographic $180 \times 360$ grid, in: Kineman J.J., Ohrenschall M.A. (Eds.), Global Ecosystems Database Ver 1.0, 1.0 ed, Boulder, United States Department of Commerce, Boulder, 1992. 